\title{
Islamic Character in Science Learning for Madrasah Ibtidaiyah Students in the 4.0 Industrial Revolution Era
}

\author{
Arghob Khofya Haqiqi ${ }^{1}$, Wakhid Fitri Albar ${ }^{2}$ \\ ${ }^{1}$ Natural Science Education Department Institut Agama Islam Negeri (IAIN) Kudus \\ ${ }^{2}$ Master Programme in Mathematics, Universitas Gadjah Mada (UGM) \\ ${ }^{1}$ Email: arghobhaqiqi@stainkudus.ac.id
}

\begin{abstract}
This study aimed to analyze and describe the development of science learning characterized by Islam for students of Islamic elementary schools in the era of the fourth industrial revolution. The existence of technological developments today leads to changes in social development. This certainly also has an impact on the character development of children, especially those at the elementary school or Islamic elementary school level. Science learning is one of learning in Islamic elementary schools, which is not only required to follow the development of these technologies but also cannot be separated from the Islamic character as a characteristic of madrasah. The research method used was literacy studies by collecting existing data from journal studies, books and other sources relevant to the problem. From the results of the study, it was found that science learning at the level of Islamic elementary schools must be in Islamic character and should follow the development of the present and existing technology. It is suggested to improve the curriculum and the science teachers' ways of teaching based on the current technology.
\end{abstract}

Keywords: Islamic character, Science learning, 4.0 Industrial Revolution

\section{INTRODUCTION}

The Law No. 20 Year 2003 concerning the National Education System explains that education is a conscious and planned effort to create a learning atmosphere and learning process so that students can actively develop their potential to have religious spiritual strength, self-control, personality, intelligence, morality and skills what are needed by themselves and Indonesians in general.

Education is very important today. The rapid development of science and technology has resulted in many changes, ranging from changes in patterns of life, social patterns of society, and culture. Therefore, education must be a shield to compensate for these all changes.

Madrasah ibtidaiyah (Islamic elementary schools), as one of the educational institutions which are officially recognized by the government, also played a role in the development of the era. Madrasas are an important educational institution in addition to developing education as well as being an Islamic dawah institution. Madrasas were originally interpreted as a way of thinking of a thinker or a group in a field of science. As time goes by, they are interpreted as a place of learning or educational institution (Chaer, 2016).

The learning in madrasah ibtidaiyah is not only about religious aspects but also about other subjects. Among the subjects are Sciences. Science learning according to Watson (2014) has some characters such as religious, honest, intelligent, caring, democratic, curious, and innovative. Therefore, science learning is not only about the complex materials, difficult calculations, and memorization of formulas, but science learning is able to form the character of students as well. By the existence of Islamic character in science learning, it will further the formation of students' character.

Madrasas are deemed necessary to harmonize between religious values and scientific knowledge. Currently, what madrasas need to integrate science into religion, is the education system called Science Interdisciplinary in Islam (Chaer, 2016). This integrative paradigm has to be developed in this modern age as a prototype of a new civilization awakening that will shift current civilization. The formation of student character is very important in the present era which is commonly called the 4.0 industrial revolution era.

This whole world or Indonesia in particular, has entered a new industrial era marked by the era of digitalization in various sectors of life. Humans as a vital subject in the growth and development of the pulse of the economy have shifted slowly but surely replaced by mechanical automation and digitalization of technology in driving the economy (Suwardana, 2017). The 4.0 Industrial Revolution can be interpreted as an industrial era where all entities can communicate with each other in real time at any time based on the use of internet technology in order to achieve the goal of achieving new value creation or optimization of existing values of each process in the industry (Prasetyo, 2018).

The existence of a correlation between the developments in the 4.0 industrial revolution era and the development of education world especially in learning science which cannot be denied the relation to the breath of Islam, is the background of the author to develop and describe the research on Islamic character 
in science learning for madrasah ibtidaiyah students in the 4.0 industrial revolution era.

\section{MATERIALS AND METHODS}

The method used in this study was literacy study. The results of the study were arranged in a descriptive narrative based on the study process from various sources of journals, books, and other sources in accordance with the problems and related to the existing topics.

\section{RESULTS AND DISCUSSION}

\section{Islamic Character in Science Learning}

Science is certainly not a new thing in which most people have heard about. The word "Science" is usually interpreted as Natural Science. Natural is related to nature, while science means knowledge. So science literally means the study of nature or studying events that occur in nature (Patta, 2006).

Today science is experiencing very rapid development, science in learning is not just memorizing formulas or theories. Science continues to be encouraged to become a reference for the progress of technology and to stay up-to-date on common issues (Haqiqi, 2018). It is believed that modern science has a less supportive view of religion. An education that brings the spirit of modern science will not be well integrated into the Islamic education system. At this point, dichotomization occurs between the fields of religion and modern science in the world of Islamic education. This ultimately causes losses between the two, because there is no reciprocal integration, so that Islamic education experiences various crisis, including conceptual crises, methodological or pedagogical institutions, and orientation crisis (Abdullah, 2003).

In order not to be a disadvantage for both science and religion, there needs to be an integration of science and religion. The study of applied-Islamic-based science is one alternative to accommodate concerns from the dichotomization of the two fields. Khoiri (2017) in his article explained there are several examples of the relationship between science and Islamic studies contained in the Qur'an as shown in Table 1 below:

Table 1. Relationship of science with Islamic studies.

\begin{tabular}{|c|c|c|}
\hline Science & Al-Qur'an & Islamic \\
\hline $\begin{array}{l}\text { Fluid is a substance that can flow. } \\
\text { For example, liquid and gas. }\end{array}$ & $\begin{array}{l}\text { And [in] the alternation of night and day and [in] } \\
\text { what Allah sends down from the sky of provision and } \\
\text { gives life thereby to the earth after its lifelessness and } \\
\text { [in His] directing of the winds are signs for a people } \\
\text { who reason. (Q.S (Al Jaatsiyah: } 5)\end{array}$ & $\begin{array}{l}\text { The order of the universe includes } \\
\text { day and night, rain and wind. }\end{array}$ \\
\hline Pressure on liquid & $\begin{array}{l}\text { [More precisely], is He [not best] who created the } \\
\text { heavens and the earth and sent down for you rain } \\
\text { from the sky, causing to grow thereby gardens of } \\
\text { joyful beauty which you could not [otherwise] have } \\
\text { grown the trees thereof? Is there a deity with Allah? } \\
\text { [No], but they are a people who ascribe equals [to } \\
\text { Him]. } \\
(Q S . \text { An-Naml/27:60) }\end{array}$ & Water as a source of life \\
\hline $\begin{array}{l}\text { Ships can sail with Floating, } \\
\text { Sinking, or even neutrally buoyant. }\end{array}$ & $\begin{array}{l}\text { And of His signs is that He sends the winds as } \\
\text { bringers of good tidings and to let you taste His mercy } \\
\text { and so the ships may sail at His command and so you } \\
\text { may seek of His bounty, and perhaps you will be } \\
\text { grateful. } \\
\text { Qs: Ar-Ruum: } 46)\end{array}$ & God's gift through today's technology. \\
\hline
\end{tabular}

From Table 1, we can find that science cannot be separated from Islamic studies. This Islamic study can be used as a form of actualization of Islamic character in science learning for students of madrasah ibtidaiyah. So, the students not only learn science from counting numbers and memorizing material and formulas, but they can also learn science with Islamic characters as well.

\section{Islamic Character in Science Learning for Students of Madrasah Ibtidaiyah in the 4.0 Industrial Revolution Era}

Natural Science Learning is learning that requires an attitude of curiosity and openness to new ideas and habits of analytical thinking. In science learning, it is expected that teachers can equip students with knowledge, understanding, and a number of abilities to develop science and technology. Therefore, school learning must emphasize understanding the science 
concept through thinking skills, critical problemsolving skills, and communication skills.

Objectively, it cannot be denied that the latest industrial revolution has a variety of advantages and major challenges that must be faced for every entity that is involved in it. Among the challenges are about education and progress for a nation and state. One of the benefits gained is finding new opportunities, but it is also followed by new challenges (Suwardana, 2017). This can also be developed in new learning in madrasas, especially in science learning.

Science learning can be in various forms, such as by inviting students to look for harmonization symbols that lie in the universe, to be interpreted as models of integration between science and religion. In one form of horticulture study material, it can be for the integration of science and religion with the model of a rose. For example, students are trained to develop their creative imagination by explaining roses, where students explain their petals which represent various cultures, mythologies, sciences, spiritual approaches, and philosophies, in which the all is centered on the head of the flower. It can also be further explained that flowers grow on the basis of human experience and petals are systems of thought built from human experience. Finally, the students are invited to understand that experience.

From the example above, we will think about the basic assumption that science and religion can and must work together to produce a deeper and richer understanding of our world. We teach students to learn to integrate science and religion in field activities even while playing (Dahar, 2011). Hence, it is possible to enhance students' understanding, that science and religion will grow together to adapt one to another. Moreover, this process gives students to understand that every model of integration between science and religion must reflect reality instead of theoretical ties.

Islamic education in the future must give priority to learn material that will help to produce scientists, technologists, and engineers, as well as other professional groups, whose roles and contributions are very important for economic progress. On the other hand, it also means that an Islamic educational institution is not just concerned with producing a kind of scientist, technologist, or engineer, who speaks religion in the same quality as the people who are produced by most public education (Dawn, 1999).

Islamic educational institutions, in this case madrasah ibtidaiyah, must have an interest in educating students to be "new-type students" who are internalized within themselves of policies and knowledge, spiritual and rational minds, creativity and moral insight, innovative power and ethical goodness, as well as ecological sensitivities which are developing harmoniously without undermining the possibility for them to achieve excellence (Chaer, 2016).

All series of learning activities are held in reference to the integration of science and Islam. In creating lesson plans within the framework of the integration, there are several elements that must be in place. First, the (cognitive) material content is developed based on basic assumptions and Islamic paradigm, that the source of all knowledge is Allah SWT while this nature as the object of knowledge is a creature that He created. Second, it forms an (affective) attitude and character by instilling faith and noble values, through both the learning process and the material or lectures in their respective fields of expertise. Third, it determines exactly what skills or abilities are obtained by students after going through the learning process. Moreover, the students will deserve a blaze of glory in their respective fields and specialties.

It has become a joint task and responsibility for every entity, especially educational institutions, furthermore madrasas as an Islamic educational institution. This is consistent with what Suwardana (2017) conveyed that educational institutions must simultaneously strengthen the literacy that is integrated into strengthening competencies in the field of scientific science, Islam, and expertise or profession so that the world of education still has high relevance in the 4.0 industrial revolution.

\section{CONCLUSIONS}

The existence of rapid technological developments in the 4.0 industrial revolution era has led to changes in social development. This certainly also has an impact on the character development of children, especially those at the elementary school or madrasah ibtidaiyah (Islamic elementary school) level. The learning in madrasah ibtidaiyah, one of which is science learning, is required to keep abreast of these technological developments. Although, it also cannot be separated from the Islamic character as a characteristic of madrasas. Science learning at the level of madrasah ibtidaiyah must be in Islamic character, and should also follow current developments and existing technologies.

\section{REFERENCES}

Abdullah, M. Amin. 2003. New Horizon of Islamic Studies Through SocioCultural Hermeneutics, Al-Jami'ah, Vol. 41, No.1.

Chaer, Moh. Toriqul. 2016. Peran Madrasah Dalam Menghadapi Era Globalisasi, MUADDIB Vol.06 No.02

Dahar, Ratna Wilis. 2011. Teori-Teori Belajar \& Pembelajaran. Jakarta: Erlangga.

Fajar, Malik. 1999. Madrasah dan Tantangan Modernitas. Bandung: Mizan

Haqiqi, Arghob Khofya , etc. 2018. Peran Madrasah dalam Pengembangan Pembelajaran Sains yang Berbasis Islam Terapan, Prosiding Konferensi Interkoneksi Islam dan Sains. Volume 1, Halaman: 29-32.

Khoiri, Ahmad, etc. 2017. Penumbuhan Karakter Islami melalui Pembelajaran Fisika Berbasis Integrasi Sains-Islam. Tadris: Jurnal Keguruan dan Ilmu Tarbiyah.Vol 02 (1) 19-31

Patta, Bundu, 2006. Penilaian Ketrampilan Proses dan Sikap Ilmiah Dalam Pembelajaran Sains di SD. Jakarta: Depdiknas 
Prasetyo, Hoedi, etc. 2018. Industri 4.0: Telaah Klasifikasi Aspek dan Arah Perkembangan Riset. J@ti Undip: Jurnal Teknik Industri, Vol. 13, No. 1

Suwardana, Hendra. 2017. Revolusi Industri 4. 0 Berbasis Revolusi Mental. Jati Unik, Vol.1, No.2, Hal. 102-110
Watson, Cate. 2014. Effective Professional Learning Communities? The Possibilities For Teachers As Agents Of Change In Schools. British Education Reseacrh Jurnal. Volume 40 Issue 1. 